\title{
SITUS JANGKUNG DAN KOMUNITAS MAANYAN
}

\section{JANGKUNG SITE AND MAANYAN COMMUNITY}

\author{
Sunarningsih \\ Balai Arkeologi Kalimantan Selatan, Jalan Gotong Royong II, RT 03/06 Banjarbaru 70711 Kalimantan Selatan; \\ email: sunarningsih@kemdikbud.go.id
}

\begin{abstract}
Abstrak. Situs pemukiman kuna Pulau Jangkung, Kabupaten Tabalong terletak di tepi aliran anak Sungai Tabalong, telah diteliti oleh Balai Arkeologi Kalimantan Selatan pada tahun 2012. Keberadaan situs tersebut cukup menarik, karena letaknya yang berada di tempat yang jauh dari pemukiman sekarang, dan berada di lereng bukit dengan aliran sungai yang mengelilinginya. Tujuan penelitian ini adalah mengetahui kapan dan siapa komunitas penghuni situs Jangkung. Oleh karena itu, artikel ini akan menggunakan data hasil penelitian tahun 2012 dan penelusuran studi pustaka untuk menjawab permasalahan tersebut. Metode yang digunakan dalam penelitian adalah deskriptif eksplanatif dengan penalaran induktif. Data hasil penelitian akan dianalisis kembali dan disintesakan dengan dukungan data pustaka sehingga akan menghasilkan sebuah interpretasi baru. Hasil dari penelitian menunjukkan bahwa situs Jangkung dihuni oleh komunitas Maanyan pada masa setelah penaklukan Majapahit di wilayah Kalimantan bagian tenggara.
\end{abstract}

Kata kunci: keramik, pemukiman kuna, Maanyan, Pulau Jangkung

\begin{abstract}
Pulau Jangkung ancient settlement site is located on the banks of Tabalong's tributary stream which had been investigated by Balai Arkeologi Kalimantan Selatan in 2012. The existence of the site is quite interesting, because it lies at a distance from the recent settlement, on the slopes hill surrounded by the river flow. This paper aims to know the chronological site and who were Jangkung's occupants community during the past. Therefore, this paper will be using research data of 2012, and literature sources to answer the problem. The method used in this research is descriptive-explanative with inductive reasoning. Research data will be reanalyzed and synthesized with literature data support that will obtain a new interpretation. Results from the study showed that the site was inhabited by Maanyan community in the aftermath of the Majapahit conquest in the southeastern part of Kalimantan.
\end{abstract}

Keywords: ceramics, ancient settlements, Maanyan, Jangkung Island

\section{PENDAHULUAN}

Daerah aliran Sungai Barito yang mengalir di dua wilayah provinsi di Kalimantan, hingga sekarang masih menjadi pilihan tempat tinggal bagi masyarakat. Di sepanjang daerah aliran sungai tersebut juga memiliki banyak bekas pemukiman kuno, baik yang berada di wilayah hilir (Provinsi Kalimantan Selatan) maupun hulu
(Provinsi Kalimantan Tengah). Boleh dikatakan bahwa pemukiman yang berada di sepanjang aliran Sungai Barito tersebut digunakan secara berkesinambungan. Meskipun demikian, dari hasil penelitian arkeologi yang telah dilakukan selama ini, ada beberapa titik pemukiman ${ }^{1}$ kuno yang sekarang tidak lagi menjadi tempat tinggal. Perpindahan tempat bermukim dari satu tempat

\footnotetext{
Pemukiman menurut kamus Bahasa Indonesia (www.Kamus Bahasalndonesia.org) adalah proses, cara, perbuatan memukimkan, sedangkan permukiman adalah daerah tempat bermukim atau perihal bermukim. Istilah pemukiman lebih cocok dipakai untuk artikel ini.
} 
ke tempat lainnya tampaknya sangat intensif dilakukan oleh masyarakat pada masa lalu. Hal tersebut disebabkan oleh berbagai alasan, yang mungkin berbeda dengan alasan sebuah pemukiman modern berpindah.

Hunian pada masa akhir prasejarah hidup secara berkelompok, pada awalnya mereka hidup berpindah-pindah untuk mendapatkan sumber makanan. Seiring dengan berkembangnya teknologi yang dikuasai, seperti domestikasi tanaman dan hewan, masyarakat tersebut mulai hidup menetap dan tetap berkelompok. Persaingan antarkelompok tampaknya sangat intensif pada masa lalu, tidak hanya pada masa prasejarah saja tetapi berlanjut hingga masa awal sejarah, bahkan ketika sebuah kerajaan terbentuk di wilayah Kalimantan bagian tenggara, sebagian masyarakat yang memilih untuk tidak menjadi bagian dari organisasi pemerintahan tersebut tetap bermukim secara terpisah dengan kelompoknya.

Berdasarkan hasil penelitian arkeologi terhadap pemukiman kuno yang berada di Daerah Aliran Sungai (DAS) Barito diketahui ada beberapa titik konsentrasi pemukiman kuno (Sunarningsih 2015: 95-99). Untuk sementara ini, yang tertua ada di daerah Barabai, tepatnya di halaman masjid tertua di Banua Lawas, yaitu Masjid Banua Halat (5304 dan 5630 BC), Banua Asam (539-695 BC), Pelajau (201-372 BC dan 117 - 130 BC) (Tim Penelitian Arkeologi 2006: 6; Hartatik 2014: 4247; Sunarningsih 2015: 95-99). Selanjutnya, situs pemukiman tua lainnya ada di wilayah Hulu Sungai Selatan, yaitu Jambu Hilir (1270 - 970 BC), Candi Agung (242 - 226 BC), Sungai Terate (429-465 BC) (Anggraeni dan Sunarningsih 2008: 124; Kusmartono dan Widianto 1997/98: 19-20; Sunarningsih 2015: 95-99). Hasil pertanggalan absolut pada masing-masing situs menggunakan analisis C14, dari sampel tiang kayu (rumah) dan arang, yang ditemukan selama penelitian. Meskipun hasil pertanggalan tersebut masih menyisakan berbagai masalah (masih belum ada pembanding dengan menggunakan sampel dan metode yang lain tetapi sementara ini masih tetap menjadi acuan untuk mengetahui kronologi hunian awal di wilayah Kalimantan Selatan. Hal tersebut didukung oleh data sejarah yang berkembang selama ini, bahwa daerah Barabai, Kandangan, dan sekitarnya memang sudah dijadikan tempat bermukim jauh sebelum masuknya pengaruh Islam. Perkembangan kerajaan Hindu Buddha berada di kawasan Amuntai dan Negara, sedangkan wilayah yang diperkirakan menjadi tempat keberadaan Nansarunai, sebuah pusat kekuasaan (negara suku/chiefdom) yang terbentuk jauh sebelum pengaruh Hindu-Buddha masuk, juga berada di wilayah yang sama, yaitu di sekitar Amuntai (sekitar wilayah Candi Agung), yang pada akhirnya dikuasai oleh kerajaan Hindu (Bae dkk. 2000: tanpa halaman). Meskipun demikian, dalam tulisannya juga disebutkan bahwa masyarakat Maanyan jauh sebelum masuknya pengaruh Hindu Buddha sudah mendiami beberapa tempat yang berada jauh di hilir Sungai Barito, yaitu antara lain di Klimbentengan, Kayutangi (Martapura), dan Muararampiau (Margasari, sekitar Candi Laras). Setelah peristiwa penyerbuan oleh Majapahit yang diketahui melalui wadian (nyanyian), masyarakat Maanyan yang tidak mau tunduk pada penguasa baru pindah ke arah hulu, antara lain di wilayah hulu Sungai Barito (Kabupaten Barito Timur, Provinsi Kalimantan Timur) dan Sungai Tabalong (Kabupaten Tabalong, Provinsi Kalimantan Selatan).

Pada tahun 2012, Balai Arkeologi Banjarmasin (sekarang Balai Arkeologi Kalimantan Selatan) melakukan penelitian di daerah Jangkung, yang berada di tepi anak Sungai Tabalong. Masyarakat mengaitkan keberadaan situs ini sebagai bagian dari Kerajaan Tanjungpuri yang ditaklukkan oleh Majapahit. Dalam kitab Nagarakrtagama disebutkan bahwa wilayah Kerajaan Tanjungpura meliputi, wilayah barat yaitu Brune dan Sukadana (Kalimantan Barat), wilayah selatan yaitu Kandawangan, Kotawaringin, Lawe, Sampit, dan Kapuas (Kalimantan Tengah), wilayah tengah yaitu Barito, Kandandangan, dan Tabalung (Kalimantan 
Selatan), wilayah Timur yaitu Tanjung kute, Pasir, Bubu, dan Sawuku (Pigeaud 1960: 16-17). Tanjungpura di wilayah Kalimantan tersebut dikuasai Majapahit pada pertengahan abad ke14 Masehi (Mulyana 1979: 146). Kewajiban daerah bawahan Majapahit yang berada di luar Pulau Jawa adalah menyerahkan upeti tahunan dan menghadap raja Majapahit pada waktu yang ditetapkan sebagai tanda kesetiaan, dan pengakuan terhadap kekuasaan Majapahit. Kerajaan-kerajaan tersebut tetap berdaulat penuh di wilayahnya (Mulyana 1997: 148). Apakah masyarakat menganggap bahwa Tanjungpuri dan Tanjungpura yang disebutkan dalam kitab tersebut sama, masih menyisakan tanda tanya. Demikian pula dengan keberadaan Nansarunai, sebuah kekuasaan yang diyakini ada sebelum daerah di sepanjang Sungai Barito tersebut, termasuk Tabalong, ditaklukkan oleh Majapahit. Apakah Tanjungpuri yang dimaksud sama dengan Nansarunai? Apabila demikian apakah Negara Dipa dan Daha yang disebutkan dalam Hikajat Banjar sama dengan Tanjungpura dalam Nagarakrtagama, masih belum jelas jawabannya.

Terlepas dari masih banyaknya pertanyaan di atas, penelitian ini akan lebih membicarakan pada situs Jangkung, yang keberadaannya masih dipertanyakan. Permasalahan yang diajukan adalah apakah situs ini memang ada keterkaitan dengan Kerajaan Tanjungpura (yang menjadi salah satu wilayah taklukan Majapahit) atau merupakan pemukiman bagi komunitas Maanyan yang tidak mau tunduk kepada penguasa baru (Majapahit) dan pindah ke arah hulu.

\section{METODE}

Penelitian ini bersifat deskriptif eksplanatif dengan menggunakan penalaran induktif (Singarimbun dan Effendi 1989: 3-5). Data yang digunakan berasal dari hasil penelitian arkeologi yang dilakukan oleh Balai Arkeologi Kalimantan Selatan di situs Jangkung. Data hasil penelitian tersebut akan dianalisis kembali, yaitu terhadap lingkungan dan temuan artefaknya. Selain itu, juga dilakukan penelusuran data pustaka yang mendukung dalam proses sintesis dan interpretasi.

\section{HASIL DAN PEMBAHASAN}

\section{Eksistensi Maanyan Sebelum Pengaruh Majapahit}

Nansarunai disebut dalam sebuah nyanyian (wadian) dari masyarakat asli, yaitu masyarakat Dayak Maanyan. Dalam nyanyian tersebut diceritakan bahwa Nansarunai dihancurkan oleh kekuasaan Majapahit, sehingga masyarakatnya tercerai berai dan berpindah ke daerah yang sampai dengan saat ini menjadi tempat tinggal mereka, yaitu di hulu Sungai Barito. Menurut Sutopo Ukip Bae, dkk. (2000: tanpa halaman) Nansarunai yang terdiri atas masyarakat Maanyan tersebut sudah mendiami DAS Barito jauh sebelum munculnya Kerajaan Dipa, sebagai hasil penaklukan Majapahit. Wilayah kekuasaan Nansarunai diyakini berada di sekitar Sungai Tabalong. Pusat kekuasaan Nansarunai tersebut menunjuk pada wilayah yang berada di sekitar wilayah Candi Agung (di seberang sungai). Pendapat lainnya menyebutkan bahwa keberadaan negara Nansarunai sendiri diperkirakan berada di sekitar Margasari, sekarang masuk wilayah Kecamatan Candi Laras, dengan penguasanya bukan dari masyarakat Dayak dan memiliki latar keagamaan yang berbeda (Kusmartono 2008: 774). Penguasa yang baru berasal dari Kerajaan Majapahit, orang Jawa. Apabila melihat wilayah Nansarunai terlihat bahwa daerah padat penduduk yang hingga sekarang masih bisa ditemui, yaitu di sepanjang Sungai Negara, Tabalong, dan Tapin memang sudah dijadikan tempat bermukim.

Selanjutnya, pada saat penguasa Majapahit mengambil alih, pemimpin Nansarunai beserta rakyatnya yang tidak mau tunduk melarikan diri ke arah hulu Sungai Barito dan mendirikan beberapa kelompok kecil yang pada saat ini mendiami wilayah Paju Epat, Paju Sepuluh, dan Banua Lima di Kabupaten Barito Utara, Provinsi Kalimantan Tengah dan Kabupaten Tabalong, 
Provinsi Kalimantan Selatan. Masyarakat Nansarunai tersebut tidak lain adalah masyarakat Maanyan yang sampai sekarang masih ada dan masih menggunakan bahasa Maanyan dalam berkomunikasi.

\section{Maanyan di Madagaskar}

Sampai dengan hari ini, masyarakat Maanyan masih menggunakan bahasa Maanyan sebagai alat komunikasi sehari-hari. Bahasa tersebut bahkan dibawa oleh masyarakat pada saat mereka berpindah ke tempat lain, berdasarkan hasil penelitian ahli bahasa, yang pertama kali diungkapkan oleh Dahl pada 1951. Hipotesa Otto Dahl menyatakan bahwa akar bahasa yang dipakai oleh masyarakat asli di Malagasi (Madagaskar) adalah bahasa yang juga dipakai oleh masyarakat di Kalimantan bagian tenggara. Selanjutnya, penelitian yang lebih intensif dilakukan oleh beberapa ahli untuk memperkuat pendapat tersebut, baik berdasarkan data arkeologi, bahasa, maupun genetik (Totanelly dan Bertoncini 2010: 1). Berdasarkan hasil penelitian terhadap masyarakat asli yang tinggal di Madagaskar dapat diperoleh gambaran bahwa secara fisik masyarakat yang tinggal di pantai dan di pedalaman sangat berbeda. Masyarakat yang tinggal di pedalaman mempunyai ciri fisik yang mirip dengan masyarakat Asia, berkulit kuning, berambut hitam lurus, dan bergantung secara ekonomi dengan padi. Masyarakat yang tinggal di pantai memiliki ciri fisik hitam, berambut keriting, dan rahang keras, yang mirip dengan masyarakat asli yang tinggal di Afrika. Selain itu, dari segi mata pencaharian kedua komunitas yang menempati dua wilayah geografis yang berbeda tersebut juga memiliki aktivitas yang berbeda. Masyarakat yang tinggal di pedalaman sangat menguasai cara bercocok tanam, terutama padi, dan menempati daerah yang subur. Berdasarkan hasil penelitian beberapa ahli dapat diperkirakan bahwa komunitas yang tinggal di pedalaman Madagaskar adalah kelompok yang lebih dulu datang, yaitu pelayar yang berbicara bahasa Austronesia. Diperkirakan mereka datang pada sekitar abad ke-7-9 Masehi untuk berocok tanam padi. Selanjutnya, datanglah komunitas yang berbahasa Bantu dari Afrika bagian timur dan membangun beberapa kerajaan di wilayah yang penghuninya jarang, yaitu di daerah pantai.

Perkiraan terjadinya migrasi masyarakat Maanyan dari Kalimantan bagian Tenggara ke Madagaskar terjadi setelah abad ke-5 Masehi diperkuat dengan keberadaan inskripsi dengan bahasa Sanskerta di Kalimantan, yaitu prasasti Yupa yang menunjukkan langgam tulisan yang berkembang pada abad tersebut. Bahasa Maanyan sendiri sudah mengambil banyak istilah dari bahasa Sanskerta. Tentunya perlu proses interaksi untuk terjadinya adopsi bahasa (SlametVelsink 1995: 87). Kenyataan tersebut juga memberi gambaran bahwa masyarakat Maanyan pada masa itu sudah sangat terbuka terhadap pengaruh dari luar. Hubungan dengan dunia luar sudah terjadi secara intensif, akibat dari adanya kegiatan perdagangan. Dari hasil interaksi dengan para pedagang tersebut, selain terjadi jual beli atau barter barang juga masuknya pengaruh dari luar yang berupa ideologi (kepercayaan/agama) dan bahasa. Selain itu, bisa jadi juga terjadi proses masuknya penguasa baru. Terlihat bahwa masyarakat Maanyan pada masa itu tidak hanya dipengaruhi oleh masyarakat dari luar, tetapi juga secara aktif ikut menyebarkan bahasa dan kebiasaan mereka ke sebuah wilayah yang sangat jauh dengan melakukan migrasi (berpindah). Apakah alasan komunitas Maanyan sehingga harus melakukan perjalanan jauh karena adanya tekanan atau konflik dari dalam (penguasa atau kelompok komunitas lain) atau karena alasan yang lain, masih belum bisa diketahui secara pasti. Yang jelas karena terjadiya proses migrasi tersebut berkisar antara abad ke-7 sampai dengan abad ke-9, tentunya tidak ada kaitannya dengan peristiwa masuknya kekuasaan Majapahit di wilayah Kalimantan bagian Tenggara tersebut.

Kenyataan penggunaan bahasa di Madagaskar yang sangat mirip dengan bahasa 
Maanyan tersebut sekaligus menjadi petunjuk bahwa aktivitas pelayaran pada masa lalu sudah dilakukan secara intensif. Tampak bahwa kemampuan berlayar masyarakat Maanyan telah mampu untuk dapat mencapai Madagaskar, sebuah pulau kecil yang berada di ujung tenggara Afrika. Sebuah perjalanan dengan jarak tempuh yang sangat panjang. Kemampuan berlayar tersebut tentunya juga didukung oleh penguasaan teknologi, baik dalam hal penguasaan pembuatan kapal dan penguasaan sistem navigasi. Sejarah sudah memberi beberapa petunjuk bentuk kapal yang bisa digunakan untuk mengarungi samudra dengan berbagai permasalahannya yang tentunya lebih kompleks dibandingkan kemampuan dalam mengarungi sebuah sungai. Salah satunya adalah kapal yang dipahatkan di dinding Candi Borobudur (relief), dan telah dibuat tiruannya untuk berkeliling dunia. Masyarakat di Kalimantan sendiri (bagian tenggara) juga mempunyai jenis kapal yang khas, yaitu jukung. Erik Peterson (2000: 9-11) telah menguraikan secara detil dalam bukunya yang berisi tentang cara pembuatan jukung dan berbagai jenisnya, dengan melakukan penelitian di Mangkutup, Desa Manusop, Desa Dusun, dan Alalak sebagai tempat membuat berbagai macam jukung. Keistimewaan jukung adalah penggunaan bahan utama perahu dari sebuah batang kayu utuh yang dilubangi dan diperlebar dengan proses pengasapan. Untuk menambahkan dinding perahu dikaitkan dengan pasak. Model perahu yang mirip dengan jukung juga ditemukan di pantai barat daya Madagaskar. Kemungkinan besar keahlian pembuatan perahu tersebut berasal dari Kalimantan, karena perahu dari Arab yang juga berlayar di wilayah Afrika menggunakan konstruksi yang berbeda (Peterson 2000: 144). Kemampuan membuat jukung oleh masyarakat Maanyan juga didukung oleh hasil penelitian Hudson yang menyatakan bahwa masyarakat Padju Epat (Maanyan) dikenal sebagai pengrajin jukung yang dijual di sepanjang Sungai Barito sebagai sumber penghasilan tambahan (Peterson 2000: 144-146).

\section{Keberadaan Situs Jangkung}

Ada seorang tokoh bernama Patih Bantar, seorang tokoh yang dikenal masyarakat Tabalong dan merupakan salah satu tokoh yang penting. Terdapat dua versi cerita mengenai Patih Bantar. Versi yang pertama meyakini bahwa tokoh ini memiliki badan yang besar dan hidup di masa Kerajaan Alengka. Kerajaan Alengka berkembang sebelum Kerajaan Bakulapura. Kerajaan Bakulapura sendiri hidup sebelum Kerajaan Tanjungpuri Nansarunai. Cerita dengan versi yang kedua meyakini bahwa Patih Bantar adalah salah satu dari 12 patih (nama patih yang lainnya, antara lain adalah Patih Ui, Patih Angan, Patih Magal) yang berada pada rombongan Kerajaan Nansarunai yang berpindah pada saat pengaruh Kerajaan Majapahit datang. Patih Bantar menyingkir sampai ke wilayah Agung Langit, atau tempat tinggi yang paling dihormati. Oleh kelompok pemerhati sejarah di Tabalong, tempat yang tinggi tersebut diyakini berada di Jangkung. Jangkung memiliki arti yang sama, yaitu tinggi (pers.comm. dengan Bapak Suryani, mantan Lurah Jangkung).

Pulau Jangkung, demikian masyarakat menyebut, adalah sebuah bukit yang termasuk dalam wilayah RT 7, Kelurahan Jangkung, Kabupaten Tabalong (lihat gambar 1). Secara astronomis Kelurahan Jangkung berada di $1^{\circ} 58^{\prime}$ $2^{\circ} 15^{\prime}$ LS dan $115^{\circ} 16^{\prime}-112^{\circ} 5^{\prime} \mathrm{BT}$, dengan luas wilayahnya 1515,21 hektar atau $27,36 \mathrm{~km}^{2}$, dan kemiringan antara $0-15 \%$, sedangkan ketinggian antara 25 - $35 \mathrm{~m}$ dpl. Situs ini mirip pulau kecil yang berupa sebuah bukit dan dikelilingi sungai. Bukit tersebut dimanfaatkan oleh pemiliknya sebagai kebun yang ditanami pisang, karet, buahbuahan, dan rumpun bambu. Penduduk menemukan fragmen keramik asing dalam jumlah banyak di salah satu sisi bukit, yang juga bekas aliran sungai dan sudah mati (guntung), di sebelah utara pulau yang merupakan ladang milik Bapak Kosasih dan ditanami pohon pisang. Letak kubur tokoh Patih Bantar berada di bagian puncak bukit, 


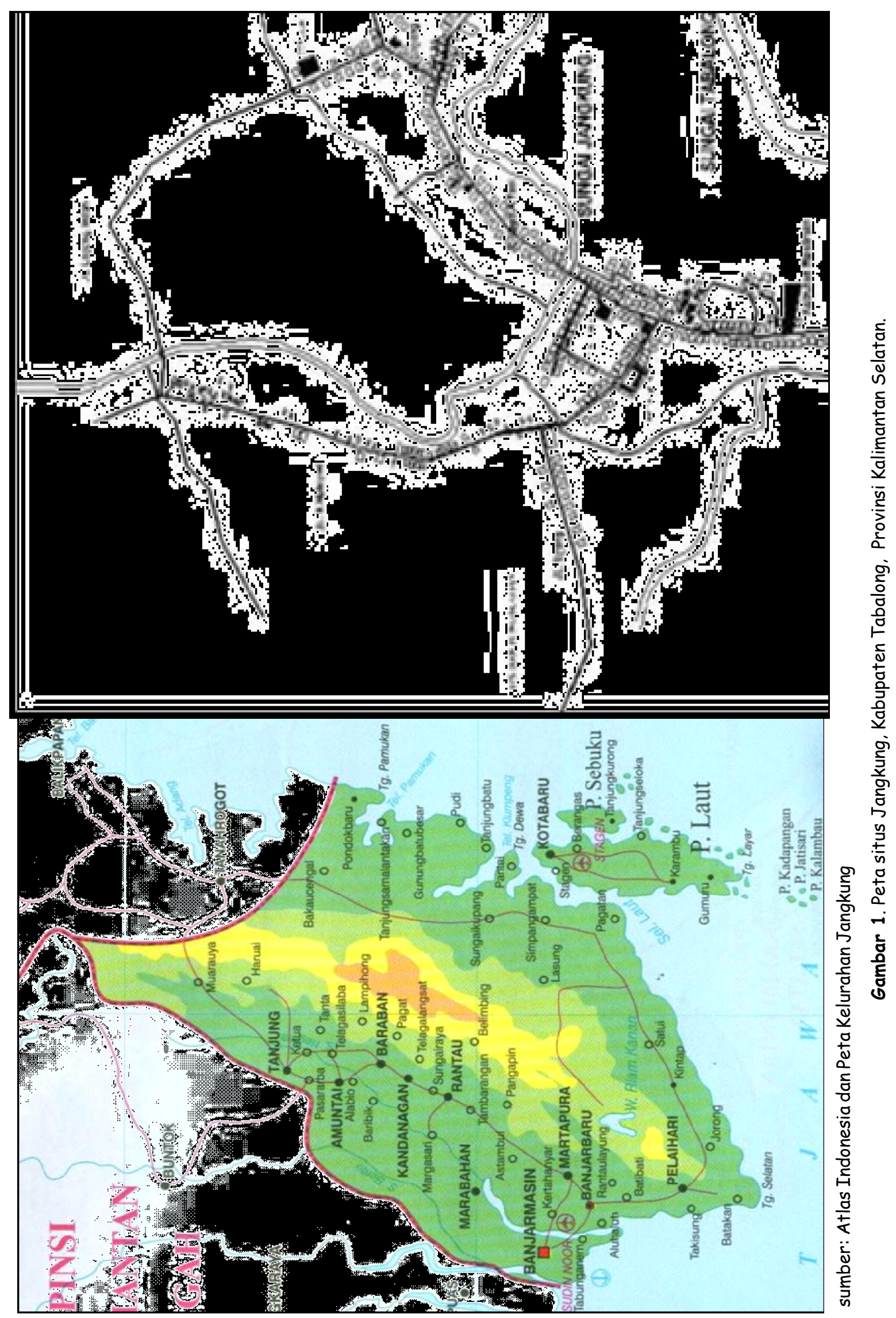


dan berada di dekat rumpun bambu. Dahulu, memang ada sebuah makam lengkap dengan nisannya yang terbuat dari kayu ulin, tetapi sekarang sudah tidak ada lagi. Bekas makam tersebut masih dikunjungi oleh masyarakat Dayak yang menganggap sebagai leluhurnya. Di sebelah selatan pulau, ditanami pohon karet dan dimiliki oleh Bapak Sulaeman.

Untuk mencapai Pulau Jangkung ada beberapa jalan alternatif yang bisa ditempuh. Jalan pertama melalui jalan beraspal di dekat Kantor Kecamatan Jangkung yang berada di wilayah RT 6, sedangkan alternatif yang kedua melalui jalan tanah menuju Dusun Ugang.

Tabel 1. Artefak temuan masyarakat di situs Jangkung.

\begin{tabular}{|c|c|c|c|c|c|c|c|}
\hline No. & BENTUK & $\begin{array}{l}\text { UKURAN } \\
(\mathrm{cm})\end{array}$ & BAHAN & $\begin{array}{c}\text { RAGAM } \\
\text { HIAS/TEKNIK }\end{array}$ & GLASIR & ASAL/PERIODISASI & KETERANG AN \\
\hline 1 & Mangkuk & $\begin{array}{l}\text { Diameter } \\
\text { tepian: } 15 \\
\text { Tinggi: } 5,8 \\
\text { Diameter } \\
\text { Kaki Cincin: } \\
5,2\end{array}$ & porselen & $\begin{array}{l}\text { Motif hias } \\
\text { ukel dan } \\
\text { geometris }\end{array}$ & $\begin{array}{l}\text { glas ir putih } \\
\text { biru } \\
\text { Underglaze }\end{array}$ & $\begin{array}{l}\text { Cina, Dinasti Qing, } \\
\text { abad ke-17-19 M }\end{array}$ & \\
\hline 2 & Mangkuk & $\begin{array}{l}\text { Diameter } \\
\text { tepian : } 15 \\
\text { Tinggi: 5,8 } \\
\text { Diameter } \\
\text { Kaki Cincin: } \\
\text { 5,8 }\end{array}$ & porselen & $\begin{array}{l}\text { Motif hias } \\
\text { ukel dan } \\
\text { geometris }\end{array}$ & $\begin{array}{l}\text { glas ir putih } \\
\text { biru } \\
\text { Underglaze }\end{array}$ & $\begin{array}{l}\text { Cina, Dinasti Qing } \\
\text { abad ke-17-19 M }\end{array}$ & \\
\hline 3 & Mangkuk & $\begin{array}{l}\text { Diameter } \\
\text { tepian: } \\
14,2 \\
\text { Tinggi: } 4,4 \\
\text { Diameter } \\
\text { Kaki Cincin: } \\
8\end{array}$ & porselen & bunga & $\begin{array}{l}\text { Glasir } \\
\text { celadon } \\
\text { tip is, tidak } \\
\text { merata }\end{array}$ & $\begin{array}{c}\text { Cina, Dinasti Song } \\
\text { Awal, abad ke-9- } \\
10 \mathrm{M}\end{array}$ & \\
\hline 4 & Piring & $\begin{array}{l}\text { Diameter } \\
\text { tepian: } \\
23,2 \\
\text { Tinggi: } 3,4 \\
\text { Diameter } \\
\text { Kaki Cincin: } \\
11,2\end{array}$ & porselen & $\begin{array}{l}\text { Polosdengan } \\
\text { cap mastrich } \\
\text { di tengah } \\
\text { bagian bawah } \\
\text { luar piring }\end{array}$ & $\begin{array}{l}\text { glasir putih, } \\
\text { pecah } \\
\text { seribu }\end{array}$ & $\begin{array}{c}\text { Ko lon ial, abad ke- } \\
20 \mathrm{M}\end{array}$ & \\
\hline 5 & Mangkuk & $\begin{array}{l}\text { Diameter } \\
\text { Kaki Cincin: } \\
6,6\end{array}$ & porselen & $\begin{array}{l}\text { Hias } \\
\text { geometris dan } \\
\text { cap dibagian } \\
\text { tengah dasar } \\
\text { mangkuk, baik } \\
\text { di dalam } \\
\text { maupun di } \\
\text { luar }\end{array}$ & $\begin{array}{l}\text { glas ir putih } \\
\text { biru } \\
\text { Underglaze }\end{array}$ & $\begin{array}{c}\text { Cina, Din as ti Ming, } \\
\text { abad ke } 15-17 \mathrm{M}\end{array}$ & \\
\hline 6 & Mangkuk & $\begin{array}{l}\text { Diameter } \\
\text { Kaki Cincin: } \\
7\end{array}$ & porselen & Flora & $\begin{array}{l}\text { Glasir putih, } \\
\text { polychrome } \\
\text { Upperglazed }\end{array}$ & $\begin{array}{c}\text { Cina, Din as ti Ming } \\
\text { abad ke } 15-17 \mathrm{M}\end{array}$ & \\
\hline
\end{tabular}




\begin{tabular}{|c|c|c|c|c|c|c|c|}
\hline No. & BENTUK & $\begin{array}{l}\text { UKURAN } \\
\text { (cm) }\end{array}$ & BAHAN & $\begin{array}{c}\text { RAGAM } \\
\text { HIAS/TEKNIK }\end{array}$ & GLASIR & ASAL/P ERIODISASI & KETERANG AN \\
\hline 7 & Piring & $\begin{array}{l}\text { Diameter } \\
\text { tepian: } 18 \\
\text { Tinggi: 4,6 } \\
\text { Diameter } \\
\text { Kaki Cincin: } \\
\text { 7,5 }\end{array}$ & porselen & $\begin{array}{l}\text { Flora su lu r- } \\
\text { suluran }\end{array}$ & $\begin{array}{l}\text { glas ir putih } \\
\text { biru } \\
\text { Underglaze }\end{array}$ & $\begin{array}{l}\text { Cina, Dinasti Ming, } \\
\text { abad ke 15-17 M }\end{array}$ & \\
\hline 8 & Piring & $\begin{array}{l}\text { Diameter } \\
\text { tepian: } \\
24,5 \\
\text { Tinggi: 5,1 } \\
\text { Diameter } \\
\text { Kaki Cincin: } \\
\text { 10,2 }\end{array}$ & Porselen & $\begin{array}{l}\text { Hias } \\
\text { geometris }\end{array}$ & $\begin{array}{l}\text { glas ir putih } \\
\text { biru } \\
\text { Underglaze }\end{array}$ & $\begin{array}{l}\text { Cina, Dinasti Qing } \\
\text { abad ke-17-19M }\end{array}$ & \\
\hline 9 & Mangkuk & $\begin{array}{l}\text { Diameter } \\
\text { tepian: } 9,5 \\
\mathrm{~mm} \\
\text { Tinggi: } 5 \\
\text { Diameter } \\
\text { Kaki Cincin: } \\
4,5\end{array}$ & Porselen & $\begin{array}{l}\text { Hias tumpal di } \\
\text { dekat dasar } \\
\text { dan cap di } \\
\text { dasar } \\
\text { mangkuk } \\
\text { bagian dalam }\end{array}$ & $\begin{array}{l}\text { glas ir putih } \\
\text { biru } \\
\text { Underglaze }\end{array}$ & $\begin{array}{l}\text { Cina, Dinasti Ming, } \\
\text { abad ke } 15-17 \mathrm{M}\end{array}$ & \\
\hline 10 & $\begin{array}{c}\text { Cepuk } \\
\text { dengan } \\
\text { tu tup nya }\end{array}$ & $\begin{array}{l}\text { Diameter } \\
\text { tepian } \\
\text { Wadah: 6,6 } \\
\text { Tinggi } \\
\text { Wadah: } 2 \\
\text { Diameter } \\
\text { Kaki Cincin } \\
\text { Wadah: } \\
\text { 4,4 } \\
\text { Diameter } \\
\text { tepian } \\
\text { Tutup: 6,6; } \\
\text { Tinggi } \\
\text { Tutup: } 1,6\end{array}$ & Porselen & $\begin{array}{l}\text { Hias } \\
\text { geometris dan } \\
\text { flora }\end{array}$ & $\begin{array}{l}\text { glas ir putih } \\
\text { biru } \\
\text { Underglaze }\end{array}$ & $\begin{array}{l}\text { Cina, Dinasti Ming, } \\
\text { abad ke 15-17 M }\end{array}$ & \\
\hline 11 & $\begin{array}{l}\text { Tutup } \\
\text { cepuk }\end{array}$ & $\begin{array}{l}\text { Diameter } \\
\text { tepian: } 6,4\end{array}$ & Porselen & $\begin{array}{l}\text { Hias pohon } \\
\text { dan } \\
\text { pemandangan }\end{array}$ & $\begin{array}{l}\text { glas ir putih } \\
\text { biru } \\
\text { Underglaze }\end{array}$ & $\begin{array}{l}\text { Cina, Dinasti Ming, } \\
\text { abad ke 15-17 M }\end{array}$ & \\
\hline 12 & Buli-buli & $\begin{array}{l}\text { Diameter: } \\
3,5\end{array}$ & Porselen & $\begin{array}{l}\text { Hias garis } \\
\text { melingkar di } \\
\text { bagian tepian } \\
\text { dan bahu }\end{array}$ & $\begin{array}{l}\text { glas ir putih } \\
\text { biru } \\
\text { Underglaze }\end{array}$ & $\begin{array}{l}\text { Cina, Dinasti Ming, } \\
\text { abad ke 15-17 M }\end{array}$ & \\
\hline 13 & Mangkuk & $\begin{array}{l}\text { Diameter: } \\
9,5 \\
\text { Tinggi: } 5 \\
\text { Diameter } \\
\text { Kaki Cincin: } \\
4,5\end{array}$ & porselen & $\begin{array}{l}\text { hias } \\
\text { upperglazed } \\
\text { motif sudah } \\
\text { aus/tidak } \\
\text { jelas }\end{array}$ & $\begin{array}{l}\text { Glasir putih, } \\
\text { upperglazed } \\
\text { coklat }\end{array}$ & $\begin{array}{l}\text { Cina, Dinasti Ming, } \\
\text { abad ke } 15-17 \mathrm{M}\end{array}$ & 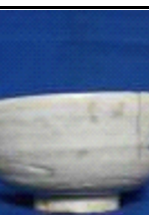 \\
\hline
\end{tabular}




\begin{tabular}{|c|c|c|c|c|c|c|c|}
\hline No. & BENTUK & $\begin{array}{l}\text { UKURAN } \\
(\mathrm{cm})\end{array}$ & BAHAN & $\begin{array}{c}\text { RAGAM } \\
\text { HIAS/TEKNIK }\end{array}$ & GLASIR & ASAL/PERIODISASI & KETERANG AN \\
\hline 14 & $\begin{array}{c}\text { Cepuk } \\
\text { dan } \\
\text { tutupnya }\end{array}$ & $\begin{array}{l}\text { Cepuk } \\
\text { ukuran } \\
\text { Diameter } \\
\text { tepian } 5 \\
\text { Diameter } \\
\text { kaki 3,5 }\end{array}$ & porselen & $\begin{array}{l}\text { Hias embos } \\
\text { ben tuk } \\
\text { geometris dan } \\
\text { flora }\end{array}$ & Glasir putih & $\begin{array}{l}\text { Cina, Dinasti Ming, } \\
\text { abad ke } 15-17 \mathrm{M}\end{array}$ & \\
\hline 15 & Piring & & porselen & $\begin{array}{l}\text { Hias flora, ada } \\
\text { medalion di } \\
\text { dasar piring }\end{array}$ & $\begin{array}{l}\text { glas ir putih } \\
\text { biru } \\
\text { Underglaze }\end{array}$ & $\begin{array}{l}\text { Cina, Dinasti Ming, } \\
\text { abad ke } 15-17 \mathrm{M}\end{array}$ & \\
\hline 16 & Buli-buli & $\begin{array}{l}\text { Diameter } \\
\text { tepian } 4,1\end{array}$ & porselen & $\begin{array}{l}\text { Hias flora dan } \\
\text { geometris } \\
\text { tumpal }\end{array}$ & $\begin{array}{l}\text { glas ir putih } \\
\text { biru } \\
\text { Underglaze }\end{array}$ & $\begin{array}{l}\text { Cina, Dinasti Ming, } \\
\text { abad ke } 15-17 \mathrm{M}\end{array}$ & \\
\hline 17 & Piring & $\begin{array}{l}\text { Diameter } \\
\text { dasar } 8\end{array}$ & porselen & $\begin{array}{l}\text { Hias garis } \\
\text { melingkar }\end{array}$ & $\begin{array}{l}\text { Glasir putih } \\
\text { pecah } \\
\text { seribu, } \\
\text { underglazed } \\
\text { biru }\end{array}$ & $\begin{array}{l}\text { Cina, Dinasti Qing } \\
\text { abad ke-18-20M }\end{array}$ & \\
\hline
\end{tabular}

Sumber: Sunarningsih 2012: 24-41.

Kelompok warga yang peduli dengan sejarah telah mengumpulkan keramik asing, baik yang masih utuh maupun yang sudah pecah dari Pulau Jangkung. Keramik asing tersebut disimpan di salah satu rumah penduduk di Dusun Ugang (RT 10), yaitu di rumah Bapak Hasani. Selain temuan fragmen keramik asing, juga ditemukan pecahan gerabah, dan pecahan logam. Hasil analisis temuan keramik asing yang ditemukan oleh masyarakat dapat dilihat pada tabel 1 .

Tabel 1 menunjukkan bahwa temuan keramik penduduk banyak merupakan keramik Cina dari masa Dinasti Ming (abad ke-15-17 M) dan Qing (abad ke-18-20 M), meskipun ada satu keramik dari masa Dinasti Song awal yang lebih tua (abad ke-9-10 M). Dan juga ditemukan keramik dari masa kolonial (abad ke-20 M), yaitu dari Eropa dan Timur Tengah.
Selanjutnya, hasil survei menemukan pecahan keramik asing di permukaan tanah, di antara pohon pisang, di bagian lahan yang melereng dari dua arah (kanan dan kiri) menuju ke arah sungai di bawahnya. Berdasarkan informasi penduduk, di sungai tempat guntung ini bermuara juga ditemukan batu dengan bentuk yang bermacam-macam. Batu seperti yang diceritakan sudah tidak dapat ditemukan lagi pada saat survei dilakukan. Sungai di muara guntung tidak berisi air (musim kemarau), dan hanya dijumpai beberapa pohon yang tumbuh di atasnya.

Berdasarkan hasil pengamatan di sekitar Pulau Jangkung ditambah dengan keterangan dari informan ${ }^{2}$, pulau ini dilalui oleh beberapa aliran anak sungai dari Sungai Jangkung, antara lain di sebelah utara terdapat aliran Lok Tegawal, Lok

2 Bapak Suryani dan Bapak Haji Husni. 
Tampang, Lok Lendang, Lok Tumiyang, dan Lok Kajang, sedangkan yang berada di selatan terdapat aliran Lok Agung yang selanjutnya mengalir ke RT 7 Kelurahan Jangkung. Aliran sungai ini kemudian bertemu dengan Sungai Ketapi.

Tim penelitian membuka tiga lubang uji (test pit) di sekitar guntung, satu kotak (TP 1) di sebelah selatan, dan satu kotak lagi (TP 2) di sebelah utara, sedangkan satu kotak lainnya (TP 3) dibuka di titik tertinggi di sebelah utara bukit (di dekat kuburan), yang berada di kebun karet. TP 3 tidak mengandung temuan, hanya di TP 1 dan TP 2 artefak ditemukan. Lapisan tanah yang mengandung temuan di kedua kotak uji tersebut terdiri atas dua layer (lihat tabel 2).

Lapisan tanah secara garis besar terdiri atas tanah pasir dan tanah lempung. Terdapat kecenderungan bahwa data artefaktual ditemukan di lapisan pasir, sedangkan lapisan tanah liat tidak mengandung temuan. Adanya fitur pada kotak TP 2 memberi indikasi adanya pembuatan lubang di lokasi tersebut, mungkin merupakan lubang untuk menanam tanaman (pisang). Kotak TP 3 hanya memiliki lapisan tanah liat yang bercampur mineral tanpa temuan. Hasil analisis stratigrafi menunjukkan bahwa hunian pada masa itu memilih tempat di kedua belah sisi guntung, puncak bukit tidak dipakai sebagai tempat hunian. Pemilihan lokasi tempat tinggal tampaknya didasari oleh berbagai pertimbangan, antara lain dekat dengan sumber air dan kemudahan akses untuk transportasi.

Temuan gerabah terdiri atas dua macam, yaitu gerabah dengan warna coklat berpenampang hitam dan gerabah merah (lihat tabel 3 dan 4). Gerabah berpenampang hitam dibakar secara terbuka sehingga tidak sempurna, dibuat dengan memakai roda putar, sedangkan gerabah merah dibuat dengan teknologi yang lebih baik, campuran bahan yang baik dan pembakaran yang sempurna. Dari jumlah fragmen yang ditemukan tampak bahwa jumlah gerabah merah sangat sedikit, yang mendominasi adalah gerabah coklat berpenampang lintang hitam, yang mempunyai bentuk periuk, mangkuk, dan kendi. Bentuk periuk memiliki diameter yang cukup besar, menunjukkan bahwa wadah ini berukuran besar. Ukuran mangkuk dan kendi tidak dapat diukur, karena fragmen yang kecil. Tutup wadah dan dasar (rata dan cincin) tidak dapat diketahui pasti merupakan tutup dan dasar dari jenis wadah yang mana, demikian juga dengan bentuk bukan wadah tidak dapat diketahui dengan pasti.

Tabel 2. Stratigrafi tanah TP 1 dan TP 2.

\begin{tabular}{|c|c|c|c|c|c|}
\hline TP. & LAYER & SPIT/kedalaman & JENIS TANAH & WARNA & KET \\
\hline \multirow[t]{3}{*}{1} & $\begin{array}{l}1 \text { ( permukaan } \\
\text { tanah) }\end{array}$ & $1-6$ & $\begin{array}{l}\text { Pasir lempungan, tekstur } \\
\text { gembur }\end{array}$ & $\begin{array}{l}\text { Abu-abu (gray) 10YR } \\
6 / 1\end{array}$ & Ada temuan \\
\hline & 2 & $7-8-9$ & $\begin{array}{l}\text { Lempung pasiran, tekstur } \\
\text { liat }\end{array}$ & $\begin{array}{l}\text { Coklat terang (light } \\
\text { brown) } 7,5 \text { YR } 6 / 4\end{array}$ & $\begin{array}{l}\text { Ada temuan, } \\
\text { lapisan ini tidak } \\
\text { rata, ada bagian } \\
\text { yang masuk di } \\
\text { spit } 8 \text { dan } 9 .\end{array}$ \\
\hline & 3 & 9 & $\begin{array}{l}\text { Lempung, tekstur liat dan } \\
\text { keras, bercampur mineral }\end{array}$ & $\begin{array}{l}\text { Merah kekuningan } \\
\text { (yellowish red) 5YR 5/6 }\end{array}$ & $\begin{array}{l}\text { Tidak ada } \\
\text { temuan }\end{array}$ \\
\hline \multirow[t]{5}{*}{2} & $\begin{array}{l}1 \text { (permukaan } \\
\text { tanah) }\end{array}$ & 1 & $\begin{array}{l}\text { Pasir lempungan, tekstur } \\
\text { gembur }\end{array}$ & $\begin{array}{l}\text { Coklat pucat (very pale } \\
\text { brown) } 10 \text { YR } 7 / 4\end{array}$ & Ada temuan \\
\hline & 2 & $2-4$ & $\begin{array}{l}\text { Pasir lempungan, tekstur } \\
\text { gembur }\end{array}$ & $\begin{array}{l}\text { Coklat (brown) 7,5 YR } \\
5 / 3\end{array}$ & Ada temuan \\
\hline & 3 & $5-8$ & $\begin{array}{l}\text { Lempung, tekstur liat dan } \\
\text { keras, bercampur mineral }\end{array}$ & $\begin{array}{l}\text { Merah kekuningan } \\
\text { (yellowish red) 5YR 5/6 }\end{array}$ & \\
\hline & $\begin{array}{l}\text { Fitur di dinding } \\
\text { utara }\end{array}$ & $6-8$ & $\begin{array}{l}\text { Pasir lempungan, tekstur } \\
\text { gembur }\end{array}$ & $\begin{array}{l}\text { Abu-abu (gray) } 7,5 Y R \\
6 / 1\end{array}$ & \\
\hline & $\begin{array}{l}\text { Fitur di dinding } \\
\text { selatan }\end{array}$ & $2-6$ & $\begin{array}{l}\text { Pasir lempungan, tekstur } \\
\text { gembur }\end{array}$ & $\begin{array}{l}\text { Abu-abu (gray) } 7,5 Y R \\
6 / 1\end{array}$ & \\
\hline
\end{tabular}

Sumber: Sunarningsih 2012: 19-20. 
Tabel 3. Temuan artefak TP 1.

\begin{tabular}{|c|c|c|c|c|}
\hline Layer & Bentuk/jumlah & Ukuran & Warna/teknologi & Ket. \\
\hline \multirow[t]{8}{*}{1} & $\begin{array}{l}\text { Badan gerabah, warna } \\
\text { hitam } 108 \text { fragmen dan } \\
\text { warna merah } 2 \text { fragmen }\end{array}$ & $\begin{array}{l}\text { Tebal pecahan } \\
\text { ge rabah } \\
\text { bervariasi, yaitu } \\
\text { antara } 0,2 \text { s.d. } \\
1,3 \mathrm{~cm}\end{array}$ & $\begin{array}{l}\text { 1) Coklat de ngan penem pang } \\
\text { lintang bagian tengah be rwarna } \\
\text { hitam, menggunakan teknologi yang } \\
\text { sederhana; } 2 \text { ) me rah, } \\
\text { menggunakan teknologi tinggi }\end{array}$ & $\begin{array}{l}\text { Sebagian besar fragmen kecil, tidak } \\
\text { da pat diketah ui m erupakan ba gian } \\
\text { dari bentuk gerabah apa, ada yang } \\
\text { be rbentuk melengkung bagian dari } \\
\text { bentuk periuk }\end{array}$ \\
\hline & $\begin{array}{l}\text { Badan gerabah berhias } \\
\text { gore s duri ikan, bentuk } \\
\text { melengkung. Jumlah } 2 \\
\text { fragmen }\end{array}$ & & $\begin{array}{l}\text { Coklat dengan pe nampang lintang } \\
\text { hitam, menngu nakan teknologi } \\
\text { sederhana }\end{array}$ & Merupakan ben tuk dari periuk \\
\hline & $\begin{array}{l}\text { Dasar gerabah bentuk } \\
\text { cincin }\end{array}$ & & $\begin{array}{l}\text { Coklat dengan pe nampang lintang } \\
\text { hitam, menggunakan teknologi } \\
\text { sederhana }\end{array}$ & $\begin{array}{l}\text { Tidak dapat diketahui merupakan } \\
\text { da sar dari bentuk ge rabah jenis apa }\end{array}$ \\
\hline & Dasar gerabah rata & $\begin{array}{l}\text { Diam eter dasar } \\
18 \mathrm{~cm}\end{array}$ & $\begin{array}{l}\text { Merah rata antara ba gian luar dan } \\
\text { dalam, menggu nakan teknologi tiggi }\end{array}$ & Merupakan bagian dari periuk \\
\hline & $\begin{array}{l}\text { Te pian gerabah dengan } \\
\text { bentuk yang melebar } \\
\text { keluar dan lurus. Jumlah } 30 \\
\text { fragmen }\end{array}$ & $\begin{array}{l}\text { Diam eter tepian } \\
\text { rata-rata besar, } \\
\text { yaitu antara } 12,4 \\
-24 \mathrm{~cm} \\
\end{array}$ & $\begin{array}{l}\text { Coklat dengan pe nampang lintang } \\
\text { hitam, menggunakan teknologi } \\
\text { rendah }\end{array}$ & $\begin{array}{l}\text { Bentuk tep ian yang melebar keluar } \\
\text { be rbentuk periuk, sedangakan yang } \\
\text { lurus me rupakan bagian dari } \\
\text { mangkuk }\end{array}$ \\
\hline & $\begin{array}{l}\text { Leher gerabah, bentuk } \\
\text { lurus (tab ung). Jumlah } 9 \\
\text { fragmen }\end{array}$ & $\begin{array}{l}\text { Tebal } 0,3 \mathrm{~cm} ; \\
\text { tinggi } 4,2 \mathrm{~cm} ; \\
\text { dan diam eter } 2,8 \\
\mathrm{~cm}\end{array}$ & $\begin{array}{l}\text { Coklat dengan pe nampang lintang } \\
\text { hitam, menggunakan teknologi } \\
\text { rendah }\end{array}$ & $\begin{array}{l}\text { Mungkin me rupakan bagian dari } \\
\text { leher se buah kendi (gogok) }\end{array}$ \\
\hline & $\begin{array}{l}\text { Tutup gerab ah, bentuk } \\
\text { bulat dan keru cut }\end{array}$ & $\begin{array}{l}\text { Bentuk bulat } \\
\text { mempunyai } \\
\text { tinggi } 2,5 \mathrm{~cm} \text { dan } \\
\text { diameter (bagian } \\
\text { atas) } 3 \mathrm{~cm} \text {. } \\
\text { Bentuk kerucut, } \\
\text { tinggi } 2,5 \mathrm{~cm} \text { dan } \\
\text { diameter (bagian } \\
\text { bawah) } 4 \mathrm{~cm}\end{array}$ & $\begin{array}{l}\text { Coklat dengan pe nampang lintang } \\
\text { hitam, menggunakan teknologi } \\
\text { rendah }\end{array}$ & $\begin{array}{l}\text { Merupakan tutup wadah bisa } \\
\text { bentuk mangkuk a tau periuk }\end{array}$ \\
\hline & $\begin{array}{l}\text { Fragmen keramik asing, } \\
\text { bentuk dari pe cahan } \\
\text { tempayan, piring, dan } \\
\text { mangkuk. Bahan } \\
\text { stoneware ( } 3 \text { fragmen }) \text { dan } \\
\text { porselen ( } 1 \text { fragmen) }\end{array}$ & & $\begin{array}{l}\text { Glasir biru puth untuk mangkuk dan } \\
\text { piring }\end{array}$ & $\begin{array}{l}\text { Frag men keramik biru putih, } \\
\text { be rasal dari dinasti Ming Akhir (16- } \\
17 \mathrm{M} \text { ) dan dinasti Qing (abad 17-18 } \\
\text { M); mangkuk); untuk fragmen } \\
\text { te mpayan antara lain mirip dengan } \\
\text { te mpayan dari Vietnam dan China } \\
\text { (abad } 18 \text { - Modern) }\end{array}$ \\
\hline \multirow[t]{4}{*}{2} & $\begin{array}{l}\text { Fragmen da sar gerabah } \\
\text { rata dan bentuk cincin }\end{array}$ & & $\begin{array}{l}\text { Coklat dengan pe nampang lintang } \\
\text { hitam, menggunakan teknologi } \\
\text { sederhana }\end{array}$ & $\begin{array}{l}\text { Bagian dari wadah, tetapi tidak } \\
\text { da pat diketah ui merupakan bagian } \\
\text { dari bentuk periuk atau mangkuk }\end{array}$ \\
\hline & $\begin{array}{l}\text { Fragmen te pian dari periuk } \\
\text { dengan bentuk tepian } \\
\text { melebar keluar }\end{array}$ & & $\begin{array}{l}\text { Coklat dengan pe nampang lintang } \\
\text { hitam, menggunakan teknologi } \\
\text { sederhana }\end{array}$ & \\
\hline & $\begin{array}{l}\text { Fragmen ba dan gera bah } \\
\text { dalam ukuran kecil, tidak } \\
\text { diketahui be ntukn ya }\end{array}$ & $\begin{array}{l}\text { Tebal badan } \\
\text { antara } 0,2-0,8 \\
\mathrm{~cm}\end{array}$ & $\begin{array}{l}\text { Coklat dengan pe nampang lintang } \\
\text { hitam, menggunakan teknoogi } \\
\text { sederhana }\end{array}$ & \\
\hline & $\begin{array}{l}\text { Fragmen ba dan gera bah, } \\
\text { rata dan bergelom bang }\end{array}$ & & $\begin{array}{l}\text { Wama merah untuk yang } \\
\text { berge lom bang, wa ma hitam untuk } \\
\text { yang rata. Mengguakan teknologi } \\
\text { tinggi }\end{array}$ & $\begin{array}{l}\text { Bagian dari sebuah wadah, tetapi } \\
\text { tidak bisa diketahui apakah dari } \\
\text { bentuk mangkuk a tau periuk }\end{array}$ \\
\hline
\end{tabular}

Sumber: Sunarningsih 2012: 21-22

Gerabah yang berada di layer 1 dan layer 2 memiliki kesamaan ciri, baik di TP 1 maupun TP 2. Demikian juga dengan keberadaan keramik asing, masing-masing lapisan mengandung temuan tersebut. Kedua lapisan budaya tersebut memiliki temuan yang sama, sehingga dapat dikatakan bahwa lapisan ini sudah teraduk. Lapisan tanah teraduk disebabkan oleh aktivitas perladangan yang secara intensif dilakukan oleh masyarakat. Selain itu, juga oleh aktivitas penggalian penduduk pada masa lalu yang percaya bahwa di tempat tersebut banyak mengandung harta karun (emas).

Keramik yang terbuat dari porselen memiliki beberapa bentuk, antara lain mangkuk dan piring, sedangkan yang berbahan stoneware memiliki bentuk guci dan tempayan. Asal keramik asing tersebut kebanyakan dari China, yaitu dari Dinasti Ming (Akhir) abad ke-17 M dan Dinasti Qing abad ke-17-18 M. Selain itu, ada juga keramik dari wilayah Asia Tenggara, yaitu Vietnam (abad ke $15 \mathrm{M})$ dan Thailand (abad ke-15-16 M). 
Dari hasil analisis artefaktual terhadap keramik asing yang ditemukan selama penelitian dapat disimpulkan bahwa pertanggalan relatif di situs Pulau Jangkung adalah hunian pada periode sekitar abad ke-15 - 17 Masehi dan mungkin masih digunakan pada masa sesudahnya (Sunarningsih 2012: 43). Komunitas ini berpindah karena alasan yang belum diketahui karena minimnya data yang didapatkan.

Fungsi situs ini nampak jelas sekali sebagai tempat bermukim yang permanen, didukung oleh kondisi geografis, dan lingkungan sekitar yang subur dengan air yang melimpah (pada masa itu), dari aliran sungai yang mengelilingi situs Jangkung. Tampaknya luas areal pemukiman dan jumlah temuan yang ada tidak menunjukkan adanya indikasi fungsi yang lain, seperti misalnya sebuah pelabuhan, sebagai tempat terjadinya transaksi perdagangan. Keramik yang ditemukan digunakan oleh masyarakat dalam kegiatan sehari-hari. Lokasi bukit Jangkung yang tidak berada langsung di tepi Sungai Tabalong, tetapi berada di tepi anak Sungai Tabalong kurang strategis apabila digunakan sebagai pelabuhan. Lingkungan situs Jangkung yang dikelilingi oleh banyak bukit dengan aliran sungai di bawahnya

Tabel 4. Temuan artefak TP 2.

\begin{tabular}{|c|c|c|c|c|}
\hline Layer & Bentuk & Ukuran & Warna & Ket. \\
\hline \multirow[t]{3}{*}{1} & $\begin{array}{l}\text { Badan gerabah } \\
\text { meru pakan bentuk dari } \\
\text { mangkuk dan periuk. }\end{array}$ & $\begin{array}{l}\text { Tebal badan an tara } \\
0,2-0,6 \mathrm{~cm}\end{array}$ & $\begin{array}{l}\text { Coklat dengan penampang } \\
\text { lintang hitam, menggunakan } \\
\text { teknologi rendah }\end{array}$ & \\
\hline & $\begin{array}{l}\text { Keramik asing, dari } \\
\text { porselen bentuk piring, } \\
\text { mangkuk kecil dan } \\
\text { mangkuk besar }\end{array}$ & $\begin{array}{l}\text { Piring mempunyai } \\
\text { ukuran diameter } \\
\text { tepian } 26 \mathrm{~cm} \text {, } \\
\text { diameter dasar } 14 \\
\text { cm. }\end{array}$ & $\begin{array}{l}\text { Warna glasir utk mangkuk biru } \\
\text { putih. Warna piring glasir hijau } \\
\text { celadon dengan hiasan wama } \\
\text { merah, hitam dan hijau }\end{array}$ & $\begin{array}{l}\text { Bentuk mangkuk dari tungku } \\
\text { Jingdezen, Dinasti Qing abad ke-17 } \\
\text { M. Piringnya adalah Swatow ware, } \\
\text { dari Dinasti Ming Akhir (abad ke-17). }\end{array}$ \\
\hline & $\begin{array}{l}\text { Tempayan dari } \\
\text { stoneware }\end{array}$ & & Tanpa glasir & \\
\hline \multirow[t]{7}{*}{2} & $\begin{array}{l}\text { Te pian dengan bentuk } \\
\text { bagian luamya } \\
\text { berg elombang }\end{array}$ & & $\begin{array}{l}\text { Coklat dengan penampang } \\
\text { lintang hitam, menggunakan } \\
\text { teknologi rendah }\end{array}$ & $\begin{array}{l}\text { Fragmen tepian ini kecil sehingga } \\
\text { tidak dapat diketahui bagian dari } \\
\text { bentuk wadah apa }\end{array}$ \\
\hline & $\begin{array}{l}\text { Te pian dengan bentuk } \\
\text { bibir melebar keluar dan } \\
\text { tebal lurus. Merupakan } \\
\text { bagian dari bentuk } \\
\text { wadah mangkuk dan } \\
\text { periuk, }\end{array}$ & $\begin{array}{l}\text { Diame ter tepian } \\
\text { bentuk pe riuk } \\
\text { antara } 14-22 \mathrm{~cm}\end{array}$ & $\begin{array}{l}\text { Coklat dengan penampang } \\
\text { lintang hitam, menggunakan } \\
\text { teknologi rendah }\end{array}$ & \\
\hline & Badan gerabah polos & $\begin{array}{l}\text { Ukuran } \\
\text { ketebalannya antara } \\
0,2-06 \mathrm{~cm}, 1-2 \\
\mathrm{~cm}\end{array}$ & $\begin{array}{l}\text { Coklat dengan penampang } \\
\text { lintang hitam, menggunakan } \\
\text { teknologi rendah }\end{array}$ & $\begin{array}{l}\text { Untuk badan ge rabah yang } \\
\text { melengkung dan berkarinasi } \\
\text { merupakan bagian dari periuk, } \\
\text { sedan gkan badan tebal }(1-2 \mathrm{~cm}) \\
\text { adalah bagian dari bentuk bukan } \\
\text { wadah }\end{array}$ \\
\hline & $\begin{array}{l}\text { Badan berhias te ra pola } \\
\text { garis-garis luru s besar } \\
\text { dan garis-garis kecil }\end{array}$ & & $\begin{array}{l}\text { Coklat dengan penampang } \\
\text { lintang dan bag ian dalam } \\
\text { berwarna hitam, menggunakan } \\
\text { teknologi rendah }\end{array}$ & $\begin{array}{l}\text { Bentuk badan berhias ini } \\
\text { melengkung, mungkin merupakan } \\
\text { bentuk periuk. }\end{array}$ \\
\hline & $\begin{array}{l}\text { Tutup gerabah dengan } \\
\text { bentuk bulat dan } \\
\text { berlubang pada bagian } \\
\text { tengah }\end{array}$ & & $\begin{array}{l}\text { Coklat dengan penampang } \\
\text { lintang warna hitam, } \\
\text { menggunakan teknologi rendah }\end{array}$ & $\begin{array}{l}\text { Merupakan tutup dari wa dah bisa } \\
\text { mangkuk, atau periuk }\end{array}$ \\
\hline & $\begin{array}{l}\text { Dasar g erabah dengan } \\
\text { bentuk cincin }\end{array}$ & & $\begin{array}{l}\text { Coklat dengan penampang } \\
\text { lintang warna hitam, } \\
\text { menggunakan teknologi rendah }\end{array}$ & \\
\hline & $\begin{array}{l}\text { Keramik asing berbahan } \\
\text { porselen dengan bentuk } \\
\text { piring dan mangkuk; } \\
\text { stoneware bentuk } \\
\text { gucitempayan }\end{array}$ & $\begin{array}{l}\text { mangkuk biru puth } \\
\text { pola geom etris, } \\
\text { tinggi } 6 \mathrm{~cm} \text {, } \\
\text { diameter tepian } 10,5 \\
\mathrm{~cm} \text {, diameter dasar } \\
7 \mathrm{~cm} \text {. Lainnya } \\
\text { fragmentaris. }\end{array}$ & $\begin{array}{l}\text { Mang kuk glasir biru putih hias } \\
\text { flora; mangkuk glasir celadon } \\
\text { tipis pecah seribu; piring besar } \\
\text { glasir biru putih pecah serbu } \\
\text { deng an warna biru yang pudar; } \\
\text { piring berglasir biru putih; } \\
\text { mangkuk glasir biru putih pola } \\
\text { geometris sudah pudar } \\
\text { Guci berglasir coklat tanpa } \\
\text { hiasan }\end{array}$ & $\begin{array}{l}\text { Mangkuk dan piring berg lasir biru } \\
\text { puth dari tungku jingd ezen, din asti } \\
\text { Qing Abad ke-17 M; Mangkuk } \\
\text { œladon tipis dari Vietnam; Piring } \\
\text { pecah seribu biru putih dari Sukothai } \\
\text { (Thailand) abad ke-15-16 M; } \\
\text { mangkuk biru putih pola geometris } \\
\text { berasal dan Vietnam (abad ke-15 M) }\end{array}$ \\
\hline
\end{tabular}

Sumber: Sunarningsih 2012: 23-24. 
yang bercabang-cabang lebih cocok digunakan sebagai tempat bermukim sekaligus tempat berlindung yang aman.

\section{Jangkung Sebagai Salah Satu Tempat Tinggal Komunitas Maanyan}

Dari hasil penelitian di situs Jangkung, yang kondisinya relatif sudah rusak akibat tingginya aktivitas pengolahan lahan di tempat tersebut serta adanya aktivitas perburuan barang berharga, mengakibatkan sulit untuk mengetahui kegiatan masyarakat yang tinggal di tempat tersebut secara lengkap. Meskipun demikian, data yang masih tersisa dan ditemukan selama penelitian tetap dijadikan dasar dalam upaya menjawab siapa yang tinggal di situs Jangkung.

Dalam mendukung aktivitas keseharian, mereka sudah menggunakan peralatan yang bagus, tidak hanya wadah dari gerabah yang mudah pecah, tetapi sudah menggunakan wadah porselen yang berasal dari luar negeri. Keberadaan keramik asing tersebut bisa menunjukkan beberapa aktivitas dan kondisi masyarakat di tempat tersebut. Jenis keramik wadah yang ditemukan, baik bentuk piring, mangkuk, maupun tempayan merupakan jenis yang memang banyak ditemukan di sepanjang Daerah Aliran Sungai Barito, bahkan sampai ke daerah yang lebih jauh, yaitu hulu Sungai Kahayan (Sunarningsih 2013: 57-67). Masyarakat Dayak yang tinggal di pegunungan tersebut juga sudah menggunakan berbagai jenis keramik seperti yang ditemukan di Jangkung. Masyarakat tidak menutup diri dengan dunia luar, mereka sudah melakukan aktivitas jual beli dengan pedagang yang membawa komoditas tersebut. Kebutuhan akan barang yang sedang menjadi tren yang sekaligus juga sangat berkaitan dengan prestis (status) seseorang juga melanda masyarakat yang tinggal di situs Jangkung. Wadah keramik yang memiliki nilai jual tinggi biasanya digunakan pada kegiatan tertentu, misalnya dalam sebuah upacara (baik daur hidup maupun daur mati). Bahkan sebagian masyarakat asli yang tinggal di wilayah
Kalimantan utara hingga sekarang masih menggunakan tempayan sebagai mahar dengan harga yang sangat tinggi. Ada juga yang memanfaatkannya (tempayan) sebagai wadah kubur dan juga bekal kubur (mangkuk dan piring) (Sunarningsih dkk. 2014: 171-174)

Peralatan yang digunakan dalam keseharian tersebut, tidak ada artefak yang bisa digunakan untuk mengetahui aktivitas masyarakat di situs Jangkung. Meskipun demikian, untuk dapat bertahan hidup tentunya mereka sudah memiliki keahlian dalam mencari sumber makanan dengan domestikasi tanaman dan hewan (bercocok tanam, beternak), selain mencari ikan di sungai yang berada tidak jauh dari tempat tinggalnya. Dukungan sumber makanan menjadi syarat utama sebuah komunitas bisa bertahan di satu tempat dalam waktu yang lama. Hal tersebut sangat berkaitan dengan pemilihan lokasi tempat tinggalnya. Hanya tempat yang ideal saja yang mampu membuat sebuah komunitas bertahan.

Komunitas di Jangkung yang berada tepi Daerah Aliran Sungai Tabalong memang lebih mengarah pada keberadaan Maanyan, dengan mempertimbangkan pada lokasi situs, pada cerita rakyat tentang Jangkung, informasi masih adanya keturunan komunitas tersebut yang masih tetap berkunjung untuk ziarah, dan kronologi situs meskipun sementara ini masih berdasarkan pada hasil pertanggalan relatif (keramik Cina) berada di kisaran abad ke-15 hingga ke-17 Masehi. Daerah Aliran Sungai Tabalong merupakan salah satu tempat yang dijadikan tujuan pelarian komunitas Maanyan yang tidak mau tunduk kepada penguasa baru, yaitu Majapahit. Masyarakat tersebut pada proses selanjutnya membentuk empat kelompok yang menghuni di empat sungai yang berbeda, yaitu 1) Kelompok Paju Sapuluh tinggal di Daerah Aliran Sungai Sirau; 2) Paju Epat tinggal di Daerah Aliran Sungai Telang; 3) Dayu tinggal di Daerah Aliran Sungai Dayu; dan 4) Banua Lima tinggal di Daerah Aliran Sungai Tabalong (Wasita 2004: 40). Secara umum, kepercayaan asli masyarakat Maanyan baik kelompok Paju Epat, Paju Sapuluh, Dayu, maupun 
Banua Lima adalah kepercayaan Kaharingan, yang masih mempercayai hal-hal yang bersifat gaib dan magis dan percaya bahwa benda mempunyai roh (animisme-dinamisme). Dalam aktivitas penguburannya, masing-masing kelompok menggunakan cara yang berbeda (Wasita 2004: 5). Cara penguburan kelompok Paju Epat dengan upacara ijambe, setelah mayat dibakar kemudian abunya diletakkan di dalam tambak. Paju Sapuluh dengan upacara marabia, tempat jasad dikuburkan selanjutnya dibangun siring kayu tiga sampai lima tingkat. Adapun kelompok Banua Lima cara penguburannya dengan upacara mambatur, di tempat kubur dibuat batur dari kayu atau semen (sekarang). Apabila melihat lokasinya, tampaknya komunitas Jangkung termasuk dalam kelompok Banua Lima, sayang sekali kubur yang menurut masyarakat berada di puncak bukit sudah tidak ada bekasnya lagi (hanya tinggal membentuk tanah yang berlubang. Menurut informasi penduduk, dulu kubur tersebut diberi tanda nisan dari kayu ulin. Sulit untuk menetapkan komunitas Maanyan penghuni situs Jangkung termasuk dalam kelompok yang mana.

Ada kecenderungan masyarakat lebih memilih lereng bukit (daerah pegunungan/hulu) dan secara geografis tempat tersebut terlindungi, tidak langsung bersentuhan dengan dengan kehidupan di luar. Salah satu masyarakat yang memilih tinggal di tempat yang tinggi adalah masyarakat Dayak (Maanyan). Semua data tampaknya mengarah kepada keberadaan kelompok Maanyan, yang berpindah setelah wilayah Kalimantan bagian tenggara tersebut dikuasai oleh Majapahit. Kerajaan Tanjungpuri yang disebutkan oleh penduduk tampaknya berbeda dengan Kerajaan Tanjungpura yang disebutkan dalam Kitab Nagarakrtagama. Dengan demikian apakah Kerajaan Tanjungpuri yang dimaksud oleh penduduk adalah Nansarunai itu sendiri, masih belum dapat dipastikan juga. Demikian juga dengan Kerajaan Dipa dan Daha yang disebutkan dalam Hikayat Banjar sebagai kerajaan yang muncul setelah penaklukan dari Majapahit, apakah memang sama dengan Kerajaan Tanjungpura dalam kitab Nagarakrtagama, atau merupakan kerajaan yang berbeda, masih juga belum dapat dipastikan.

\section{PENUTUP}

Beberapa titik pemukiman kuno telah ditemukan dan diteliti, terutama oleh Balai Arkeologi Kalimantan Selatan, dan sebagian sudah diketahui kronologinya, baik secara relatif maupun absolut, termasuk situs Jangkung. Meskipun demikian, masih banyak yang belum bisa diketahui dengan lebih jelas, terutama komunitas yang menempati hunian kuno tersebut. Kesulitan yang dihadapi lebih banyak dipengaruhi oleh minimnya jumlah (kuantitas) dan kualitas data yang didapatkan. Kebanyakan data yang ditemukan saat penelitian, sudah rusak dan hilang akibat aktivitas, baik yang dilakukan secara sengaja oleh masyarakat (karena kegiatan pertanian dan penjarahan) maupun akibat proses alam. Selain itu, pemukiman yang sebagian besar berada di tempat yang strategis tersebut juga secara berulangkali dihuni oleh masyarakat dalam rentang waktu yang panjang.

Minimnya data yang ditemukan di situs Jangkung tampaknya lebih dipengaruhi oleh tingginya aktivitas pengolahan lahan di situs setelah tempat tersebut ditinggalkan oleh penghuninya. Cerita yang berkembang di masyarakat bahwa tempat di sekitar guntung tersebut angker, setidaknya telah memberi pengaruh terhadap aktivitas pencarian barang antik di tempat tersebut berkurang. Data yang berhasil dikumpulkan juga tidak bisa menggambarkan aktivitas masyarakat yang tinggal pada abad ke-15 hingga abad ke-17 Masehi tersebut secara lengkap. Meskipun demikian, data yang ada memberi petunjuk bahwa situs Jangkung merupakan sebuah hunian komunitas Maanyan yang kemungkinan berpindah ke tempat tersebut setelah terjadi penaklukan 
Majapahit (pada pertengahan abad ke-14 M). Mereka memilih tempat yang tersembunyi, dan memiliki jalur yang mudah dan banyak alternatifnya untuk keluar, jika sewaktu-waktu harus meninggalkan tempat tinggalnya lagi karena berbagai sebab. Pada saat komunitas tersebut memutuskan untuk berpindah lagi, tidak dapat dijelaskan melalui data arkeologi yang ditemukan.
Selanjutnya, masyarakat tidak lagi menggunakan wilayah situs sebagai tempat bermukim, mereka lebih memilih untuk tinggal di tepian jalan besar yang memudahkan mereka dalam beraktivitas. Kemana komunitas yang tinggal di situs Jangkung tersebut berpindah juga masih menjadi misteri. Tampaknya masih diperlukan penelitian lanjutan guna mengetahui persebaran titik pemukiman di sekitar situs Jangkung.

\section{DAFTAR PUSTAKA}

Anggraeni dan Sunarningsih. 2008. "The Prehistoric settlement at Jambu Hilir, South Kalimantan Province, Indonesia". Bulletin of the Indo-Pasific Prehistory Association 28: 120-126.

Bae, Sutopo Ukip; Djanang G. Bandan, dan Martinus. 2000. Suku Dayak Maanyan, Banjar, dan Merina di Madagaskar. Belum terbit.

Hartatik. 2014. "Penelitian Pelajau". Laporan Penelitian Arkeologi. Banjarbaru: Balai Arkeologi Banjarmasin.

Kusmartono, Vida Pervaya R. 2008. "Pemerintahan Early State Negara Dipa di Kalimantan Bagian Tenggara". HIm. 774- 780 dalam Pertemuan IImiah Arkeologi IX di Kediri 23-28 Juli 2002. Jakarta: Ikatan Ahli Arkeologi Indonesia.

Kusmartono, Vida Pervaya Rusianti dan Harry Widianto. 1997/1998. "Ekskavasi Situs Candi Agung Kabupaten Hulu Sungai Utara Kalimantan Selatan". Berita Penelitian Arkeologi Balai Arkeologi Banjarmasin 2: 1 - 26
Mulyana, Slamet. 1979. Nagarakretagama dan Tafsir Sejarahnya. Jakarta: Bhratara Karya Aksara.

Peterson, Erik. 2000. Jukung Boats from the Barito Basin, Borneo. Roskilde: The Viking Ship Museum.

Pigeaud, TH. 1960. Java in The Fourtheenth Century. The Hague: Martinus Nijhoff.

Singarimbun, Masri dan Sofian Effendi (ed.). 1987. Metode Penelitian Survai. Jakarta: LP3ES.

Slamet-Velsink, Ina E. 1995. Emerging Hierarchies: Processes of Stratificaion and Early State Formation in The Indonesian Archipelago: Prehistory and The Ethnographic Present. Leiden: KITLV Press.

Sunarningsih. 2012. "Penelitian Pemukiman Kuna di Situs Jangkung, Tabalong, Kalimantan Selatan". Laporan Penelitian Arkeologi. Banjarbaru: Balai Arkeologi Banjarmasin.

Sunarningsih. 2013. "Penelitian Akeologi DAS Kahayan, Kalimantan Tengah". Laporan 
Penelitian Arkeologi. Banjarbaru: Balai Arkeologi Banjarmasin.

Sunarningsih, dkk. 2014. JejakArkeologi di Wilayah Perbatasan Utara Kalimantan, editor Agus Aris Munandar. Banjabaru: Balai Arkeologi Banjarmasin.

Sunarningsih. 2015. "DAS Barito dan Jejak Kehidupan Masyarakat Masa Proto Sejarah". HIm. 85-116 dalam Budaya di Kawasan Pegunungan Meratus dalam Perspektif Arkeologi, editor Bambang Sulistyanto. Banjarbaru: Balai Arkeologi Banjarmasin.

Tim Penelitian Arkeologi. 2006. "Laporan Hasil Kajian Arkeologi Situs Masjid Keramat, Banua Halat, Kabupaten Tapin, Provinsi
Kalimantan Selatan". Laporan Penelitian Arkeologi. Banjarbaru: Balai Arkeologi Banjarmasin dan Dinas Kebudayaan dan Pariwisata Kabupaten Tapin.

Totanelly, Sergio dan Stefanie Bertoncini. 2010. "Origin and Evolutionary History of the Malagasy". HIm. 1-9 dalam Encyclopedia of Life Scinces (ELS). Chichester: John Wiley \& Sons. Ltd.

Wasita. 2004. "Penelitian Perbedaan Ritual Kematian pada Tiga Kelompok Budaya di Masyarakat Dayak Maanyan di Barito Timur". Laporan Penelitian Arkeologi. Banjarbaru: Balai Arkeologi Banjarmasin. 